\title{
Soundscape manipulation enhances larval recruitment of a reef-building mollusk
}

Ashlee Lillis, DelWayne R Bohnenstiehl, David B Eggleston

Marine seafloor ecosystems, and efforts to restore them, depend critically on the influx and settlement of larvae following their pelagic dispersal period. Larval dispersal and settlement patterns are driven by a combination of physical oceanography and behavioral responses of larvae to a suite of sensory cues both in the water column and at settlement sites. There is growing evidence that the biological and physical sounds associated with adult habitats (i.e. the "soundscape") influence larval settlement and habitat selection; however, the significance of acoustic cues is rarely tested. Here we show in a field experiment that the free-swimming larvae of an estuarine invertebrate, the eastern oyster, respond to the addition of replayed habitat-related sounds. Oyster larval recruitment was significantly higher on larval collectors exposed to oyster reef sounds compared to nosound controls. These results provide the first field evidence that soundscape cues may attract the larval settlers of a reef-building estuarine invertebrate. 


\title{
Soundscape manipulation enhances larval recruitment of a reef-building mollusk
}

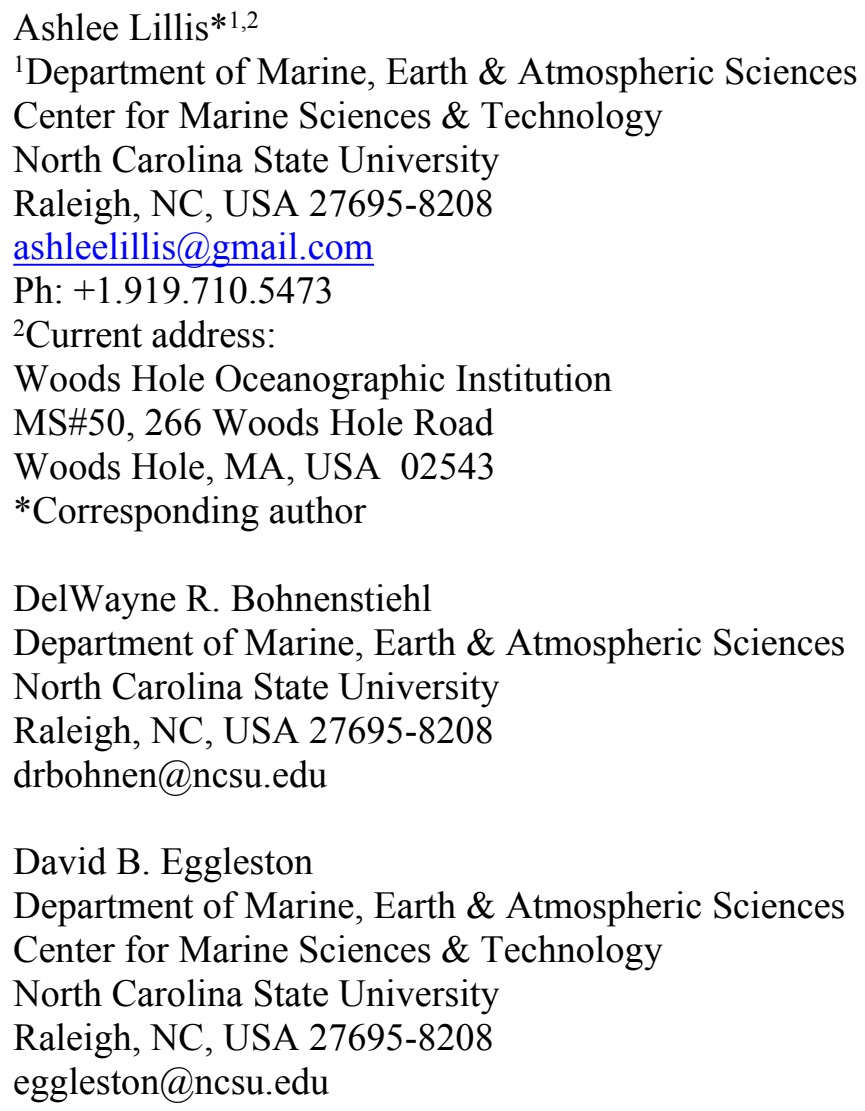

Statement of authorship: AL, DB and DE designed experiments. AL conducted field experiments, processed samples, and analysed results. DB and DE provided materials and equipment. AL wrote the first draft of the manuscript, and all authors contributed substantially to revisions.

\begin{abstract}
Marine seafloor ecosystems, and efforts to restore them, depend critically on the influx and settlement of larvae following their pelagic dispersal period. Larval dispersal and settlement patterns are driven by a combination of physical oceanography and behavioral responses of larvae to a suite of sensory cues both in the water column and at settlement sites. There is growing evidence that the biological and physical sounds associated with adult habitats (i.e. the "soundscape") influence larval settlement and habitat selection; however, the significance of acoustic cues is rarely tested. Here we show in a field experiment that the free-swimming larvae of an estuarine invertebrate, the eastern oyster, respond to the addition of replayed habitat-related sounds. Oyster larval recruitment was significantly higher on larval collectors exposed to oyster reef sounds compared to no-sound controls. These results provide the first field evidence that soundscape cues may attract the larval settlers of a reef-building estuarine invertebrate.
\end{abstract}




\section{Introduction:}

Most marine benthic communities are established and maintained via the settlement of larvae, following the development and dispersal of planktonic early life stages of fish and invertebrates. Larval habitat selection and settlement to suitable juvenile and adult habitat is critical for subsequent survival and reproductive success, and ultimately shapes species distributions and their population dynamics (Gaines \& Roughgarden, 1985; Caley et al., 1996). Locating favorable settlement sites in a vast ocean environment following days to months in the water column presents a significant challenge. While most larvae are relatively weak swimmers compared to the speed at which currents transport them, they use a complex suite of cues to encounter and select settlement habitat (Rittschof et al., 1998; Kingsford et al., 2002). Larval orientation and settlement cues include changes in salinity, tidal direction and turbulence that can aid larvae trying to move from oceanic to estuarine environments, as well as odors and bacterial films that help larvae settle on advantageous substrates and in sufficient proximity to one another to facilitate future reproductive success as adults (Rittschof et al., 1998; Forward Jr., Tankersley \& Rittschof, 2001). Patchy marine ecosystems such as reefs, seamounts and deep-sea vents may be especially difficult to encounter by larvae without broad-scale cues. Physical and chemical characteristics of the water column and seafloor (e.g. flow, light, habitat odors, texture) can influence larval swimming and settlement behaviors at multiple scales (Bourget, 1988; Butman, Grassle \& Webb, 1988; Kingsford et al., 2002), and settlement outcomes are likely the result of complicated interactions of larvae with environmental variables; however, their effect on larval settlement in the field is seldom directly measured.

An emerging area of research in marine ecology is the role that underwater sounds play as a cue for larval orientation and settlement of fishes and invertebrates. Habitat-related soundscapes (the combination of sounds forming an immersive acoustic environment at a particular location) may 
represent a valuable cue for a variety of larvae because these underwater sounds can indicate both the presence and biophysical characteristics of particular habitat types, and sounds can travel independent of currents over greater distances compared to other habitat cues (e.g. chemical odor) (Montgomery et al., 2006; Cotter, 2008; Lillis, Eggleston \& Bohnenstiehl, 2014ab). Recent studies have established underwater sound as an orientation and settlement cue for a variety of fish and crustacean larvae, particularly in coral and rocky reef systems (Tolimieri, Jeffs \& Montgomery, 2000; Simpson et al., 2005; Stanley, Radford \& Jeffs, 2012). However, this phenomenon has not been tested in estuarine ecosystems, where high habitat diversity supports a large array of commercially and ecologically important species producing planktonic larvae. Because of their ecological role as a habitat-creating species in estuaries, as well as their economic importance and global demise, we sought to test whether the sounds of oyster reefs could enhance recruitment of larval oysters (Crassostrea virginica). The specific sensory mechanism by which invertebrate larvae may detect acoustic stimuli has not been determined, but late-stage larval oysters possess both exterior cilia and statocyst sensory structures (Kennedy, Newell \& Eble, 1996), which have been shown to be responsive to acoustic particle motion in other aquatic invertebrates (Rogers \& Cox, 1988; Budelmann, 1992; Zhadan, 2005).

Populations of reef-building bivalve molluscs of the family Ostreidae create important intertidal and subtidal biogenic habitats throughout temperate estuarine and coastal ecosystems worldwide (Gutiérrez et al., 2003; Beck et al., 2011; Maslo, 2014), including the Atlantic and Gulf coastlines of North America where oyster reefs were once vast prominent features (Jackson et al., 2001). Reefbuilding organisms such as these generate conspicuous habitat that is vital in providing shelter for numerous associated fish and invertebrates (high local abundance and diversity) and also in carrying out a range of ecosystem services in these highly exploited and degraded systems, such as enhancing benthic-pelagic coupling and nutrient cycling via filtration of large amounts of material from the water 
93 column, as well as sequestering carbon in their shells as they grow (Dame, Zingmark \& Haskin, 1984;

94 Maslo, 2014). Moreover, oysters are an economically valuable resource, but native populations are

95 now less than $5 \%$ of their historical abundances due to fishing pressure, oyster bed destruction, habitat degradation and disease (Jackson et al., 2001; Beck et al., 2011). Ecosystem restoration efforts to recover the economic and ecological benefits of oyster reef habitat have become common; however, restoration failures have highlighted the need to better understand oyster life history and previously unconsidered aspects of their biology (Geraldi et al., 2013; Maslo, 2014).

We recently reported that the soundscapes of subtidal oyster reefs in Pamlico Sound, North Carolina, USA have distinct acoustic properties compared to surrounding soft mud bottoms, with reef soundscapes comprised of higher levels of sound across frequencies produced by soniferous reefdwellers such as snapping shrimp and oyster toadfish (Lillis, Eggleston \& Bohnenstiehl, 2014a). Additionally, experiments using cultured oyster larvae indicate that oyster reef sound can increase settlement in small experimental chambers, suggesting that a larval response to reef sound could facilitate encounter and influence oyster recruitment patterns (Lillis, Eggleston \& Bohnenstiehl, 2013, 2014b). To advance our understanding of the ecological significance of the observed larval settlement response to sound by oyster larvae, the present study tests if replayed sounds from preferred adult habitat influence recruitment of free-swimming larvae in a natural setting.

\section{Materials and Methods:}

We measured the effect of replayed oyster reef sound on oyster larval recruitment by comparing the density of newly settled oysters (termed "spat") on collectors deployed in a mud flat area with or without added recorded reef sound. Two experimental areas were constructed at a field site in West Bay, Pamlico Sound, NC. Submersible speakers were deployed with spat collectors placed 3 meters 
116 from the speaker (Fig. 1). Eight trials lasting 3-5 days were conducted during July and August,

117 alternating the sound treatment between the two experimental areas. For each trial, the sound replay

118 treatment used recordings taken from an oyster reef site more than $2 \mathrm{~km}$ away. Permission to conduct

119 fieldwork in Pamlico Sound waters and the West Bay oyster reserve was granted by the North Carolina

120 Division of Marine Fisheries permit numbers 708396 and 1012889.

Collectors for larval oyster settlers were constructed of 10 cleaned adult oyster shells (their preferred settlement substrate) strung on a $\sim 15 \mathrm{~cm}$ piece of wire. Each replicate came from five or six collectors located $>1$ meter apart and 3 meters from a speaker, suspended $\sim 1 \mathrm{~m}$ from the seabed (Fig. 1). To avoid inter-site differences in larval delivery both experimental sites were positioned parallel to the axis of the dominant current direction in the bay, situated 500 meters apart and equidistant from the West Bay oyster reserve ( $>2 \mathrm{~km}$ away) (Fig. 1). The location was selected to allow the no sound control treatment to be as representative of off-reef soft-bottom soundscape as possible. The 500 meter site separation was also intended to minimize interference from the sound replay treatment at the control site, while

131 still exposing treatments to the same larval pool. During previous acoustic surveys, elevated sound

132 levels associated with reef environments were found to diminish by $15-20 \mathrm{~dB}$ and be spectrally similar

133 to soft-bottom habitat soundscapes at $500 \mathrm{~m}$ from reefs (Lillis, Eggleston \& Bohnenstiehl, 2014a, see 134 Fig. 8). 
137 A library of recordings collected in July \& August of 2010 and 2011 were used as the sound broadcast

138 for the "sound added" treatments. A different recording was randomly selected for each of the eight

139 trials, and consisted of 15 one-minute files from the West Bay oyster reserve, looped continuously to

140 provide a constant “oyster reef” replay. Sound replay systems consisted of a submersible speaker

141 (LL916, Lubell Labs, Columbus, Ohio; frequency response: 0.2-20kHz) connected to a surface buoy

142 containing a power amplifier (Peavey IPA 1502), using a handheld digital media player (Apple iPod)

143 as audio input, and powered by a $12 \mathrm{~V}$ battery.

144 The acoustic conditions during trials were monitored using DSG acoustic recorders

145 (Loggerhead Instruments, Sarasota, FL, USA), each equipped with an HTI-96 hydrophone (High-Tech

146 Inc., Gulfport Mississippi) with a flat frequency response between $\sim 0.1$ and $30 \mathrm{kHz}$. The DSG

147

148

149

150

151

152

153

154

155

156

157

158

159

instruments digitize acoustic data using a 16-bit resolution written to a standard solid-state SD memory

card. A recorder was deployed with spat collectors $3 \mathrm{~m}$ from the speaker at each experimental site, with the hydrophone sensor positioned at $1 \mathrm{~m}$ from the seabed, and programmed to record for 1-minute at 10 -minute intervals for the duration of a trial (sampling rate $=50 \mathrm{kHz}$ ). Acoustic data are available to characterize the soundscape generated at the sound replay sites for all trials except trial 4 , but due to instrument unavailability or malfunction, acoustic monitoring was not possible at the no sound site for all trials (see supplementary data).

Analysis of recordings collected during trials showed that the average root-mean-square broadband sound pressure level recorded at the site with replayed sound treatment ranged between $125.4-135.9 \mathrm{~dB}$ re $1 \mu \mathrm{Pa}$, compared to $110.3-115.9 \mathrm{~dB}$ re $1 \mu \mathrm{Pa}$ recorded at the control site with no replayed sound. Replayed reef sound recordings primarily consisted of snapping shrimp and oyster toadfish calls, differing from the no sound control treatment acoustic composition largely in frequencies $>800 \mathrm{~Hz}$ (Fig. 2b,c). Site recordings during trials confirmed that the acoustic treatments 
160

161

162

163

164

165

166

167

168

169

170

171

172

173

174

175

176

177

178

179

180

\section{Results:}

were distinct in frequency composition (Fig. 2b,c), and that the relative acoustic spectra were similarly shaped to the original reef and off-reef soundscapes (Fig. 2a), although sound levels in upper

frequencies $(>1 \mathrm{kHz})$ were not as low at the "no sound" treatment sites as previously measured for offreef soft-bottom habitat. This could be the result of a small influence of the nearby sound replay treatment on the entire experimental area, temporal differences in the off-reef soundscape compared to the recordings from the previous year, or additional sound sources at the site. Nonetheless, the acoustic monitoring during trials demonstrates that the replayed sound treatment was effective in substantially increasing sound levels in reef-associated frequencies, and producing a distinct soundscape at the manipulated treatment sites.

\section{Statistical Analysis}

We tested the null hypothesis that the number of recruits on collectors exposed to replayed sound will be the same as the number on collectors not exposed to replayed sound, using an exact binomial test, with an expected proportion of 0.5 , to estimate the probability of observing $\boldsymbol{k}$ or more recruits on the replayed sound collectors given $\boldsymbol{n}$ total recruits during an experimental trial:

$$
\begin{gathered}
p(\geq k, n, 0.5)=1-\sum_{j=0}^{k-1}\left(\begin{array}{l}
n \\
j
\end{array}\right) 0.5^{j}(1-0.5)^{n-j} \\
\left(\begin{array}{c}
n \\
j
\end{array}\right)=\frac{n !}{j !(n-j) !}
\end{gathered}
$$


Oyster settlement varies throughout the summer reproductive period, and therefore there was a significant effect of trial date on total recruitment, as the majority of settlement during the study period occurred during the latter part of August (Fig. 3). A significantly higher proportion of oyster recruits were found at the replayed sound site for the each of the first six out of eight trials (Fig. 3). In these trials, between $68.3-100 \%$ of larvae recruited on collectors at sound treatment sites (Fig.3, Table 1). There was no difference in recruitment between treatments in the two late August trials, which were conducted during a period of peak larval settlement (Fig. 3). Pooled over the duration of the experiments, collectors exposed to replayed sound received $58.4 \%$ of the total oyster recruitment $(\mathrm{p}<0.0001, \mathrm{n}=1685)$.

The first six experiments show an average of $83 \%$ of the recruitment occurring on the sound replay collectors. These differences are significant with $p(\geq k, n, 0.5)$ ranging from $<0.0001$ to 0.0384 for the individual experimental trails. The last two experiments, which exhibit much higher overall recruitment rates, show slightly fewer recruits on the sound replay collectors; however, these differences are not significant (Table 1).

\section{Discussion:}

This study provides field evidence that sound influences settling oyster larvae and is the first to indicate that an estuarine invertebrate actively selects substrate associated with the acoustic cues from its preferred adult habitat. These results demonstrate that protection or enhancement of reef soundscape characteristics should be included in the management and restoration of this important estuarine reefbuilding species, and that sounds from oyster reefs may be used to enhance larval settlement in oyster hatchery operations that support aquaculture. The use of chemical cues, biofilms and attractive substrates (Alfaro et al., 2006; Roberts \& Watts, 2010; Li et al., 2014) are commonly incorporated in 
aquaculture and restoration settings to promote larval settlement. The results of the experiments reported here suggest that soundscape characteristics should additionally be considered in endeavors to optimize larval settlement conditions. In our experiments, larval recruitment was higher on collectors in reef sound replay treatments compared to no added sound, but further trials using a positive control (i.e. white noise played at the same sound level as the reef sound replay) will be needed to fully assess whether larvae respond specifically to habitat-related sound or if general elevated sound levels induce a response.

Field experiments in which the densities of newly settled attached organisms are measured unavoidably integrate patterns of both larval settlement and early post-settlement processes, since some amount of juvenile mortality will occur before observations can be made (Keough \& Downes, 1982).

In this experiment it is therefore not possible to confirm that the differences between recruitment on sound versus no sound spat collectors were due to larval settlement processes. However, given the relatively short trial periods (3-5 days), and prior results showing elevated settlement to soundscape treatments in larval cultures (Lillis, Eggleston \& Bohnenstiehl, 2013), it is most likely that the recruitment differences are the result of habitat selection and active larval response to the replayed sound. Moreover, if the acoustic manipulation was predicted to have an effect on post-settlement mortality, we would anticipate opposite or null results since the oyster reef sound replay would be expected to attract more predators than the no sound added control. While this study measured effects of elevated sound on initial recruitment only, and further study is required to test if the addition of reef sound could lead to long-term differences in oyster density, previous studies have found that annual juvenile oyster recruitment correlates with spatial patterns of spatfall, despite high levels of postsettlement mortality (Newell et al., 2000). Thus, we would predict that differences in spat density 
227 produced by soundscape variation could contribute to larger scale patterns of oyster abundance and 228 distribution.

The lack of a statistically significant oyster recruitment response in the last two of eight field trials may have been due to very high larval availability during August when there is a peak in oyster spat settlement in Pamlico Sound (Eggleston et al., 2011), such that high recruitment densities swamped any sound treatment effect. The Pamlico Sound estuarine system is substrate limited for oysters (Geraldi et al., 2013), so it is unsurprising that larval settlement occurs with less selectivity under high larval supply. At higher densities more individuals in a population will occupy sub-optimal habitat (Rosenzweig, 1991) and in this experiment we found that recruitment patterns do not relate to the acoustic conditions when the larval pool is at its largest. In previous studies, substrate related chemical cues were found to be less influential on settlement patterns for barnacle larvae settling later in the reproductive season (Jarrett, 1997), and larval sensitivity to cues is known to decrease over the larval period for many species (Gibson, 1995; Elkin \& Marshall, 2007). Despite the lack of significant effect of replayed sound on recruitment in the final two trials, the overall effect of sound was statistically significant, and our results suggest that the influence of an acoustic settlement cue might be particularly significant under conditions where larvae are limited.

Given the significance of habitat selection in the lifecycle of oysters and other reef-building organisms, and the unprecedented threats these ecosystems currently face, understanding the drivers of the settlement process is key to successful prediction of population dynamics, and accurate biophysical models of larval recruitment. This study reveals a previously unrecognized effect of the soundscape on a key ecological process for an ecosystem engineer. Establishing the influence of sounds on the early stages of weakly swimming reef-building organisms has broad implications for marine ecology, 
249 including marine conservation and aquaculture programs, and underscores the importance of the 250 ambient acoustic environment as a landscape-scale structuring component of benthic ecosystems.

251

252

253

254

255

256

257

258

259

\section{References:}

Alfaro AC, Copp BR, Appleton DR, Kelly S, Jeffs AG. 2006. Chemical cues promote settlement in larvae of the green-lipped mussel, Perna canaliculus. Aquaculture International 14:405-412.

Beck MW, Brumbaugh RD, Airoldi L, Carranza A, Coen LD, Crawford C, Defeo O, Edgar GJ, Hancock B, Kay MC, Lenihan HS, Luckenbach MW, Toropova CL, Zhang G, Guo X. 2011. Oyster reefs at risk and recommendations for conservation, restoration, and management. BioScience 61:107-116.

Bourget E. 1988. Barnacle larval settlement: the perception of cues at different spatial scales. Behavioral adaptation to intertidal life. Plenum Press, New York:153-172.

Budelmann BU. 1992. Hearing in nonarthropod invertebrates. In: Webster DB, Fay RR, Popper AN eds. The evolutionary biology of hearing. Springer-Verlag, 141-155.

Butman CA, Grassle JP, Webb CM. 1988. Substrate choices made by marine larvae settling in still water and in a flume flow. Nature 333:771-773.

Caley MJ, Carr MH, Hixon MA, Hughes TP, Jones GP, Menge BA. 1996. Recruitment and the local dynamics of open marine populations. Annual Review of Ecology and Systematics 477-500.

Cotter A. 2008. The "soundscape" of the sea, underwater navigation, and why we should be listening more. In: Payne A, Cotter J, Potter T eds. Advances in fisheries science: 50 years on from Beverton and Holt. John Wiley and Sons, 451-471.

Dame RF, Zingmark RG, Haskin E. 1984. Oyster reefs as processors of estuarine materials. Journal of Experimental Marine Biology and Ecology 83:239-247. 
272 Eggleston DB, Efland B, Plaia GR, Puckett BJ, Rindone R, Pierson KP. 2011. Ecological Performance

273

274

275

276

277

278

279

280 and Recreational Fishing Impacts of Large-Scale, Sub-Tidal Oyster Restoration. Newport, NC, USA: NC Coastal Federation.

Elkin C, Marshall DJ. 2007. Desperate larvae: influence of deferred costs and habitat requirements on habitat selection. Marine Ecology Progress Series 335:143-153.

Forward Jr. RB, Tankersley RA, Rittschof D. 2001. Cues for metamorphosis of brachyuran crabs: An overview. Amer. Zool. 41:1108-1122.

Gaines S, Roughgarden J. 1985. Larval settlement rate: A leading determinant of structure in an ecological community of the marine intertidal zone. Proceedings of the National Academy of Sciences of the United States of America 82:3707-3711.

Geraldi NR, Simpson M, Fegley SR, Holmlund P, Peterson CH. 2013. Addition of juvenile oysters fails to enhance oyster reef development in Pamlico Sound. Marine Ecology Progress Series 480:119-129.

Gibson G. 1995. Why be choosy? Temporal changes in larval sensitivity to several naturally-occurring metamorphic inducers in the opisthobranch Haminaea callidegenita. Journal of Experimental Marine Biology and Ecology 194:9-24.

Gutiérrez JL, Jones CG, Strayer DL, Iribarne OO. 2003. Mollusks as ecosystem engineers: the role of shell production in aquatic habitats. Oikos 101:79-90.

Jackson JBC, Kirby MX, Berger WH, Bjorndal KA, Botsford LW, Bourque BJ, Bradbury RH, Cooke R, Erlandson J, Estes JA, Hughes TP, Kidwell S, Lange CB, Lenihan HS, Pandolfi JM, Peterson CH, Steneck RS, Tegner MJ, Warner RR. 2001. Historical overfishing and the Recent Collapse of Coastal Ecosystems. Science 293:629-637.

Jarrett JN. 1997. Temporal variation in substratum specificity of Semibalanus balanoides (Linnaeus) cyprids. Journal of Experimental Marine Biology and Ecology 211:103-114. 
296 Kennedy VS, Newell RIE, Eble AF. 1996. The Eastern Oyster: Crassostrea virginica. Maryland Sea

297

298

299

300

301

302

303

304

305

306

307

308

309

310

311

312

313

314

315

316

317

318 Grant College, $760 \mathrm{p}$.

Keough MJ, Downes BJ. 1982. Recruitment of marine invertebrates: the role of active larval choices and early mortality. Oecologia 54:348-352.

Kingsford MJ, Leis JM, Shanks A, Lindeman KC, Morgan SG, Pineda J. 2002. Sensory environments, larval abilities and local self-recruitment. Bulletin of Marine Science 70:309-340.

Li Y-F, Guo X-P, Yang J-L, Liang X, Bao W-Y, Shen P-J, Shi Z-Y, Li J-L. 2014. Effects of bacterial biofilms on settlement of plantigrades of the mussel Mytilus coruscus. Aquaculture 433:434441.

Lillis A, Eggleston DB, Bohnenstiehl DR. 2013. Oyster larvae settle in response to habitat-associated underwater sounds. PLoS ONE 8:e79337.

Lillis A, Eggleston DB, Bohnenstiehl DR. 2014a. Estuarine soundscapes: distinct acoustic characteristics of oyster reefs compared to soft-bottom habitats. Marine Ecology Progress Series 505:1-17.

Lillis A, Eggleston DB, Bohnenstiehl DR. 2014b. Soundscape variation from a larval perspective: the case for habitat-associated sound as a settlement cue for weakly swimming estuarine larvae. Marine Ecology Progress Series 509:57-70.

Maslo B. 2014. Cascading effects of global oyster reef loss on the health of estuaries. In: Coastal Conservation. Cambridge University Press, 131.

Montgomery JC, Jeffs A, Simpson SD, Meekan M, Tindle C. 2006. Sound as an orientation cue for the pelagic larvae of reef fishes and decapod crustaceans. Advances in Marine Biology 51:143-196.

Newell RIE, Alspach GS, Kennedy VS, Jacobs D. 2000. Mortality of newly metamorphosed eastern oysters (Crassostrea virginica) in mesohaline Chesapeake Bay. Marine Biology 136:665-676. 
319 Rittschof D, Forward RB, Cannon G, Welch JM, McClary M, Holm ER, Clare AS, Conova S, McKelvey LM, Bryan P, van Dover CL. 1998. Cues and context: larval responses to physical and chemical cues. Biofouling 12:31-44.

Roberts RD, Watts E. 2010. Settlement of Haliotis australis larvae: role of cues and orientation of the substratum. Journal of Shellfish Research 29:663-670.

Rogers PH, Cox M. 1988. Underwater sound as a biological stimulus. In: Atema J, Fay RR, Popper AN, Tavolga WN eds. Sensory biology of aquatic animals. New York: Springer-Verlag, 131149.

Rosenzweig ML. 1991. Habitat selection and population interactions: the search for mechanism. The American Naturalist 137:S5-S28.

Simpson SD, Meekan M, Montgomery J, McCauley R, Jeffs A. 2005. Homeward sound. Science 308:221.

Stanley JA, Radford CA, Jeffs AG. 2012. Location, location, location: finding a suitable home among the noise. Proceedings of the Royal Society B: Biological Sciences 279:3622-3631.

Tolimieri N, Jeffs A, Montgomery JC. 2000. Ambient sound as a cue for navigation by the pelagic larvae of reef fishes. Marine Ecology Progress Series 207:219-224.

Zhadan PM. 2005. Directional sensitivity of the Japanese scallop Mizuhopecten yessoensis and Swift scallop Chlamys swifti to water-borne vibrations. Russian Journal of Marine Biology 31: 2835.

Acknowledgments: We are grateful to J. Peters and R. Dunn for assistance in field experiment development and execution, to B. Puckett for additional field assistance, and to D. McVeigh and S. Brown for lab sample processing. Thank you to J. Luczkovich and D. Kamykowski, who gave feedback on the initial design of this study. Funding and support was provided by NSF (OCE-1234688 \& ISO-1210292) as well as the PADI Foundation (\#5145) and a National Shellfisheries Association Student Research Grant to AL. 
Figure 1 (on next page)

Experimental setup schematic.

Figure 1. Design of the experimental sites, showing a pair of underwater speaker deployments separated by 500 meters, producing two distinct soundscape treatments. Larval collectors, constructed of non-living oyster shells, were arranged around each speaker unit. 


\section{Sound Replay}

\section{No Sound Added}

Amplifier, battery,

$\&$ audio player

Amplifier, battery,

$\&$ audio player

$500 \mathrm{~m}$ 


\section{Figure 2 (on next page)}

Acoustic power spectra for original and replayed reef recordings, compared to off-reef and "no sound" control recordings.

Figure 2. (A) Power spectral analysis of original 15-minute recordings used as sound replay treatments from July \& August 2011. For comparison, the black line represents the acoustic spectrum for a 15-minute recording made in off-reef soft-bottom habitat during July 2011. Power spectral densities were estimated using the median spectra obtained from a series 0.5-sec duration non-overlapping Hanning-windowed data segments spanning each 15minute recording (FFT size: 32768 points, frequency resolution: $1.5 \mathrm{~Hz}$ ). Acoustic conditions recorded at the two treatment sites during the experimental field replay are shown for two trials in (B) 7/13-7/16 and (C) 8/23-8/27. Red lines represent the recorded replayed sound at the collector sites; Black lines represent ambient sound level during the same time period at the control (no sound) collector sites. The median power spectral densities for treatments in (B) and (C) were generated from a series of non-overlapping 0.5-sec duration Hanningwindowed data segments spanning each 1-minute recording. 
A.

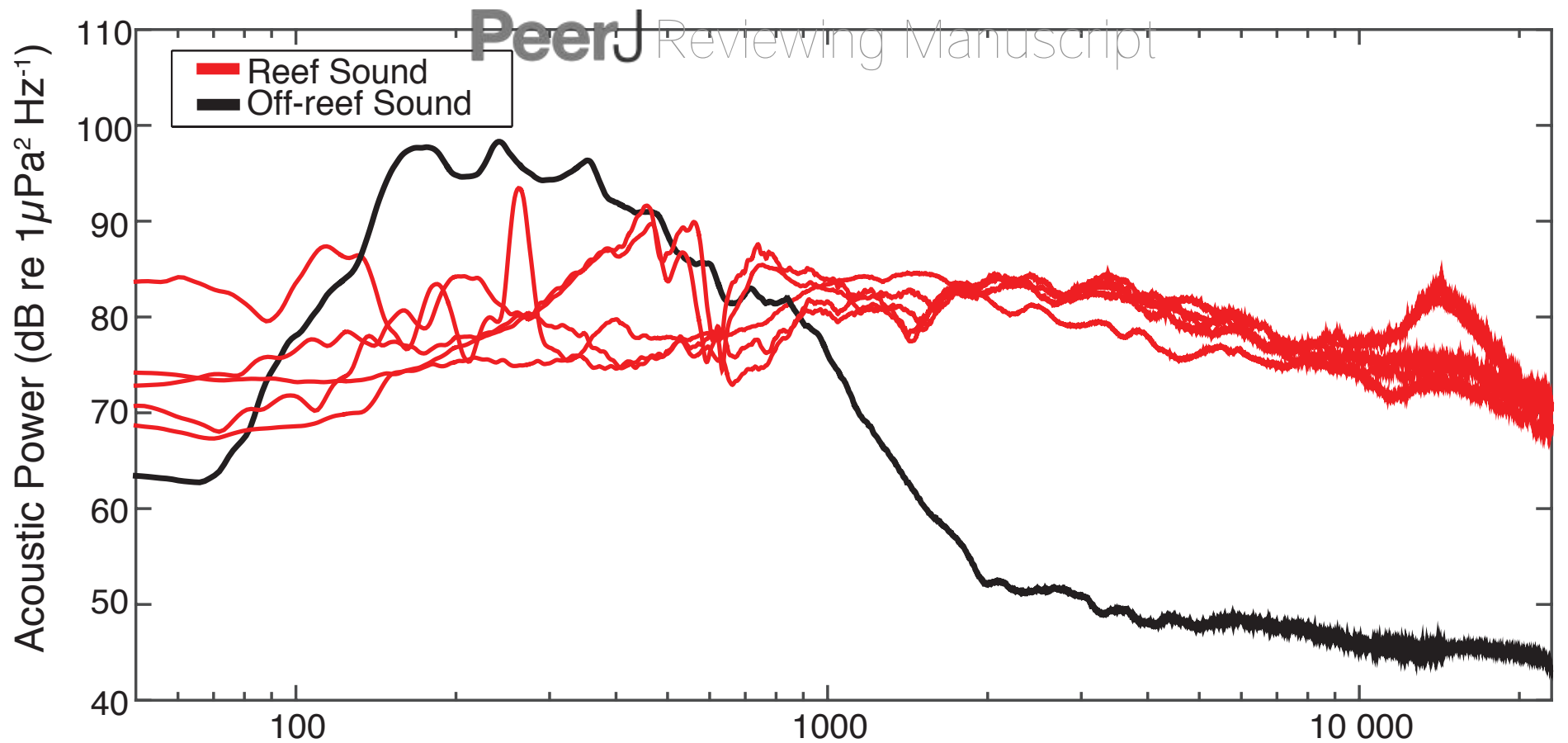

B.

Frequency $(\mathrm{Hz})$

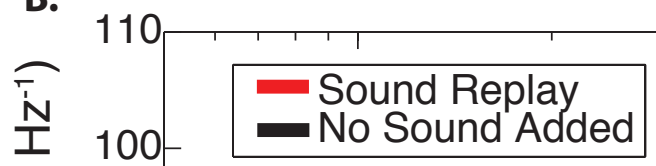

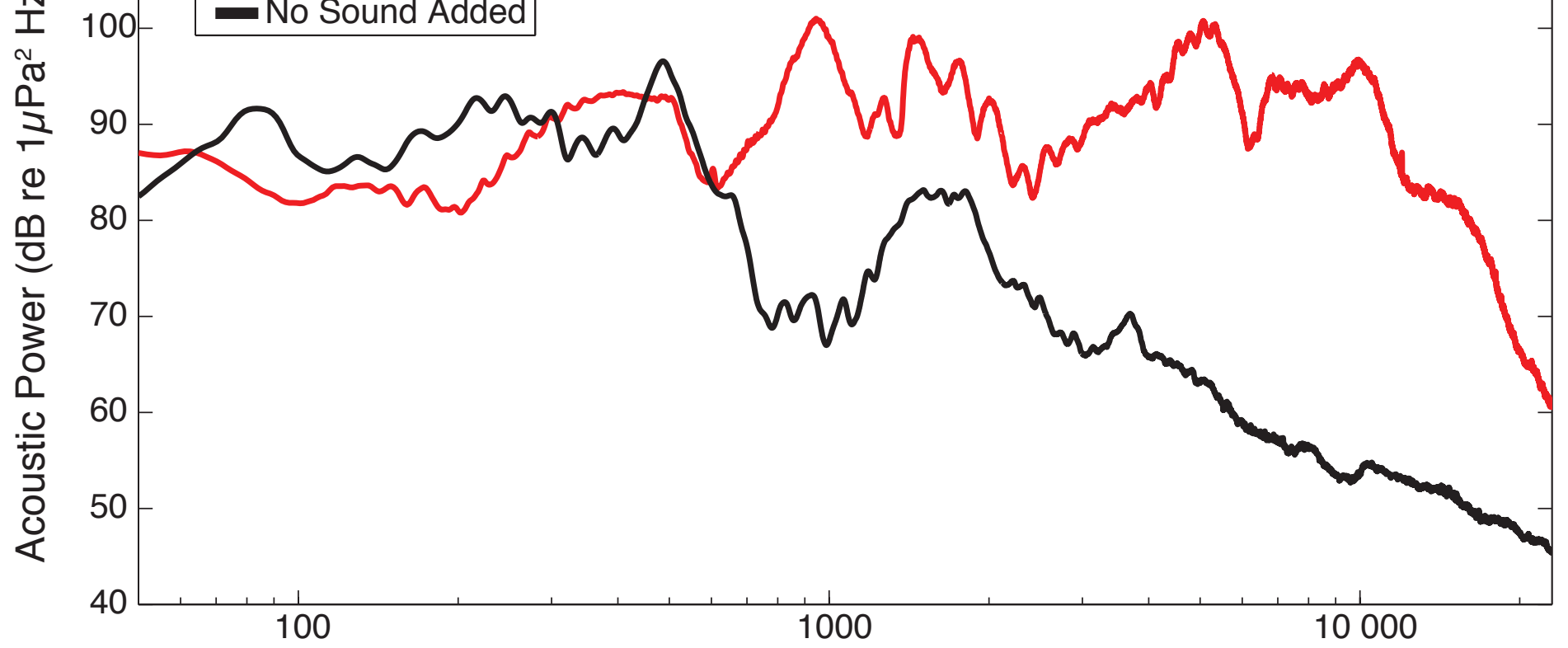

C.

Frequency $(\mathrm{Hz})$

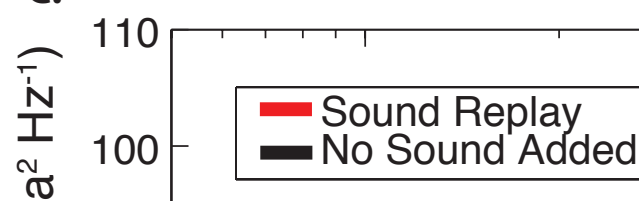

$\stackrel{0}{2}$

(1)

$\underline{m}$

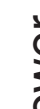

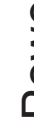

产 60 -

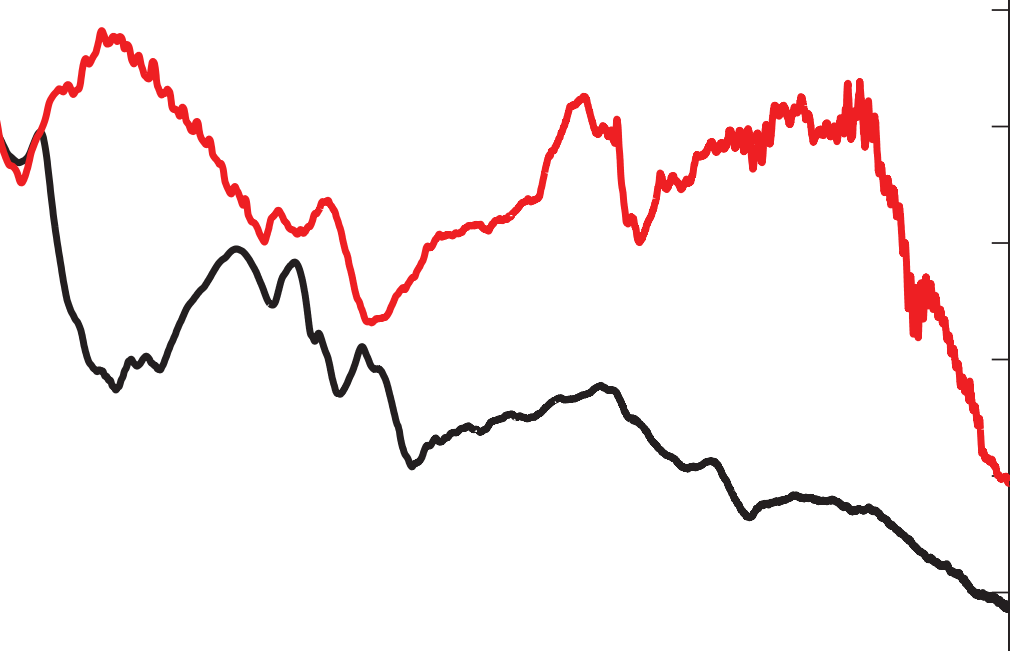

Frequency $(\mathrm{Hz})$ 
Figure 3 (on next page)

Oyster recruitment on spat collectors exposed to different acoustic treatments.

Figure 3. Comparison of recruitment on collectors exposed to reef sound replay and collectors with no added sound, in each of eight trials. Shown as (A) mean recruitment per collector ( \pm 1 S.E.), and (B) proportional recruitment between the two treatments in each trial. 
A.

Peer_Reviewing_Manuscript

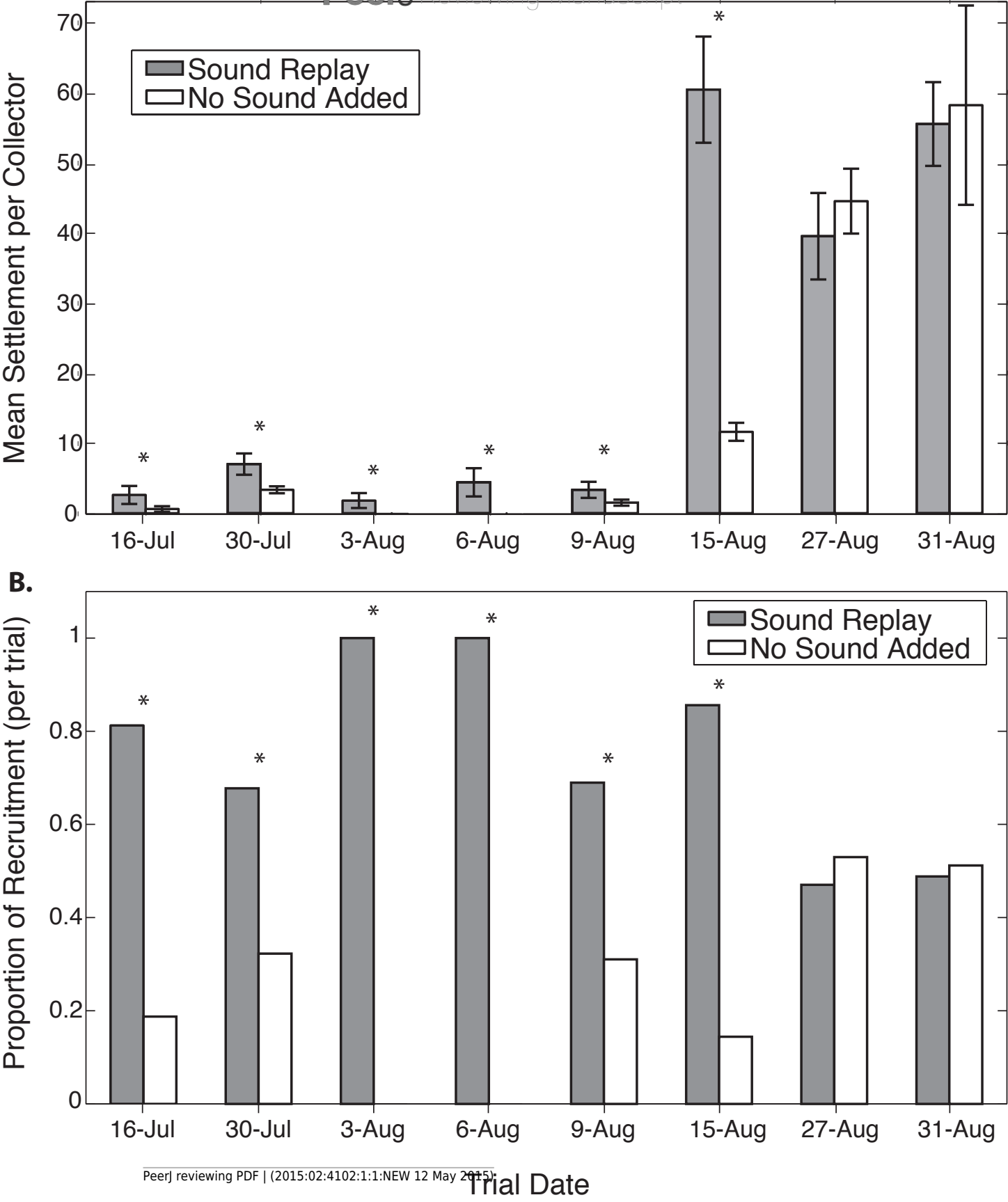


Table $\mathbf{1}$ (on next page)

Summary of experimental trials

Table 1. Summarized experimental trial information and results.

* Probability of observing $\mathrm{k}$ or more spat on the replayed sound collectors, given $\mathrm{n}$ total recruits and an expected proportion equal to 0.5 . For pooled data: $p(\geq k, n, 0.5)<0.0001$, $k=984, n=1685$ 
2 Table 1. Summarized experimental trial information and results.

3

\begin{tabular}{|l|c|c|c|c|c|}
\hline $\begin{array}{c}\text { Trial dates } \\
\text { (2012) }\end{array}$ & $\begin{array}{c}\text { Trial length } \\
\text { (hours) }\end{array}$ & $\begin{array}{c}\text { No. collectors } \\
\text { per treatment }\end{array}$ & $\begin{array}{c}\text { Total spat count } \\
\text { n }\end{array}$ & $\begin{array}{c}\text { \% Spat on collectors } \\
\text { with sound replay (k) }\end{array}$ & $p(\geq \mathrm{k}, \mathrm{n}, 0.5)^{*}$ \\
\hline 13-16 Jul & 72 & 5 & 16 & $75.7(12)$ & 0.0384 \\
\hline 26-30 Jul & 96 & 6 & 63 & $68.3(43)$ & 0.0026 \\
\hline 30 Jul - 3 Aug & 96 & 5 & 9 & $100.0(9)$ & 0.0020 \\
\hline 3-6 Aug & 72 & 5 & 22 & $100.0(22)$ & $<0.0001$ \\
\hline 6-9 Aug & 72 & 6 & 29 & $69.0(20)$ & 0.0307 \\
\hline 10-15 Aug & 120 & 5 & 360 & $85.6(308)$ & $<0.0001$ \\
\hline 23-27 Aug & 96 & 6 & 504 & $47.0(237)$ & 0.9164 \\
\hline 27-31 Aug & 96 & 6 & 682 & $48.8(333)$ & 0.7171 \\
\hline
\end{tabular}

4 * Probability of observing $\mathrm{k}$ or more spat on the replayed sound collectors, given $\mathrm{n}$ total recruits and an expected proportion 5 equal to 0.5 . For pooled data: $p(\geq k, n, 0.5)<0.0001, \mathrm{k}=984, \mathrm{n}=1685$ 